\title{
PENGARUH PEMANFAATAN MEDIA SOSIAL WHATSAPP TERHADAP HASIL BELAJAR PENDIDIKAN AGAMA HINDU DAN BUDI PEKERTI
}

\author{
Ni Wayan Ayunita Padmiyani ${ }^{1}$, Gede Eka Puja Dyatmika ${ }^{2}$, Ni Made Ria Taurisia Armayani ${ }^{3}$ \\ ${ }^{123}$ Institut Agama Hindu Negeri Gde Pudja Mataram \\ Coresponding author: Ni Wayan Ayunita Padmiyani \\ Email: niwayanayunitapadmiyani@gmail.com
}

\begin{abstract}
This study aims to determine the effect of the use of WhatsApp social media on the learning outcomes of Hindu religious education and character for class $X$ students at SMK Negeri 4 Mataram in the 2020/2021 academic year. This study uses a quantitative approach and is an ex post facto research using correlational associative analysis. Ex post facto research is research that examines causal relationships that are not manipulated or treated (designed and implemented) by the researcher. Data were collected using questionnaires and documentation. The data was analysed by product moment correlation. The results of the study indicate that there is an effect of the use of WhatsApp social media on the learning outcomes of Hindu religious education and character for class X students at SMK Negeri 4 Mataram in the 2020/2021 academic year. The magnitude of the influence of the use of WhatsApp social media on the learning outcomes of Hindu religious education and the character of class $X$ students $\left.{ }_{(r x y}\right)$ is 0.378 , while the contribution of WhatsApp social media is $14.28 \%$. This means that there is another factor of $85.72 \%$ of the learning outcomes of Hindu religious education and character for class $X$ students at SMK Negeri 4 Mataram. The conclusion of this study, there is an effect of the use of WhatsApp social media on the learning outcomes of Hindu religious education and character for class $X$ students at SMK Negeri 4 Mataram in the 2020/2021 academic year, with the contribution of using WhatsApp social media by $14.28 \%$. Base on the research result, applied social media WhatsApp can be use in other learning.
\end{abstract}

Keywords: Social Media, WhatsApp, Learning Outcomes

\begin{abstract}
Abstrak
Penelitian ini bertujuan untuk mengetahui pengaruh pemanfaatan media sosial WhatsApp terhadap hasil belajar Pendidikan Agama Hindu dan Budi Pekerti siswa kelas X di SMK Negeri 4 Mataram tahun ajaran 2020/2021. Penelitian ini menggunakan pendekatan kuantitatif dan merupakan penelitian ex post facto dengan menggunakan analisis asosiatif jenis korelasional. Penelitian ex post facto yaitu penelitian yang meneliti hubungan sebabakibat yang tidak dimanipulasi atau diberi perlakuan (dirancang dan dilaksanakan) oleh peneliti. Data dikumpulkan dengan menggunakan kuesioner dan dokumentasi. Teknik analisis data menggunakan korelasi product moment. Hasil penelitian menunjukkan bahwa terdapat pengaruh pemanfaatan media sosial WhatsApp terhadap hasil belajar Pendidikan Agama Hindu dan Budi Pekerti siswa kelas X di SMK Negeri 4 Mataram tahun ajaran 2020/2021. Besarnya pengaruh pemanfaatan media sosial WhatsApp terhadap hasil belajar Pendidikan Agama Hindu dan Budi Pekerti siswa kelas X $\left(\mathrm{r}_{\mathrm{xy}}\right)$ 0,378, sementara kontribusi media sosial WhatsApp adalah sebesar 14,28\%. Ini berarti ada faktor lain sebesar $85,72 \%$ terhadap hasil belajar Pendidikan Agama Hindu dan Budi Pekerti siswa kelas X di SMK Negeri 4 Mataram. Simpulan dari penelitian ini adalah ada pengaruh pemanfaatan media sosial WhatsApp terhadap hasil belajar Pendidikan Agama Hindu dan Budi Pekerti siswa
\end{abstract}


kelas X di SMK Negeri 4 Mataram tahun ajaran 2020/2021, dengan kontribusi pemanfaatan media sosial WhatsApp sebesar 14,28\%. Sehingga pembelajaran dengan menggunakan media sosial WhatsApp dapat diterapkan pada pembelajaran lainnya.

Kata Kunci: Media Sosial, WhatsApp, Hasil Belajar

\section{PENDAHULUAN}

Pendidikan adalah usaha sadar dan terencana untuk mewujudkan suasana belajar dan proses pembelajaran agar peserta didik secara aktif mengembangkan potensi dirinya untuk memiliki kekuatan spiritual keagamaan, pengendalian diri, kepribadian, kecerdasan, akhlak mulia, serta keterampilan yang diperlukan dirinya, masyarakat, bangsa dan Negara (UU Sisdiknas Nomor 20 Tahun 2003). Keberhasilan dalam menyampaikan materi sangat terganggu pada kelancaran interaksi komunikasi antara guru dengan peserta didik akibat dari pandemi Corona virus diseases 2019 (Covid-19) ini yang telah memberikan dampak signifikan terhadap berbagai sektor, terutama pendidikan. Oleh karena itu pemerintah memberikan kebijakan untuk tetap berada di rumah dengan melakukan kegiatan belajar dalam jaringan (daring) untuk seluruh Pelajar Sekolah Dasar, Menengah Atas maupun Perguruan Tinggi. Beberapa media yang banyak dimanfaatkan oleh lembaga pendidikan untuk belajar daring yaitu seperti WhatsApp, Youtube, Google Class Room, Zoom Meetings, Microsoft Teams, dan Google Meets. Namun, masih banyak siswa yang kurang terampil dalam menggunakan media pembelajaran daring seperti Zoom Meetings, Microsoft Teams, dan Google Meets. Hal tersebut juga dialami oleh para guru khususnya guru yang mengajar mata pelajaran Pendidikan Agama Hindu dan Budi Pekerti di SMK Negeri 4 Mataram. Kebijakan yang diambil dalam pelaksanaan pembelajaran daring tentu memiliki hambatan dalam proses pelaksanaanya, seperti keterbatasan kuota internet, peserta didik yang belum terampil dalam menggunakan media pembelajaran, kurangnya interaksi antara peserta didik dengan pendidik dalam proses pembelajaran dan peserta didik kurang mendapatkan kebebasan dalam menerima materi dan bertanya kepada gurunya terhadap materi yang diajarkan. Oleh karena itu dalam pembelajaran daring maupun pembelajaran tatap muka yang dilaksanakan secara terbatas, guru mata pelajaran Pendidikan Agama Hindu dan Budi Pekerti di SMK Negeri 4 Mataram memanfaatkan media sosial WhatsApp. Guru memanfaatkan grup WhatsApp untuk berdiskusi masalah pelajaran yang belum dipahami, bertanya seputar tugas, memotivasi siswa untuk semangat belajar ataupun memberikan informasi berupa pengumuman melalui grup WhatsApp kelas.

Penelitian yang dilakukan oleh Kamil dan Nuryadin (2018) dengan judul penelitian "Pengaruh Penggunaan Media WhatsApp (WA) Group Terhadap Hasil Belajar Peserta Didik Pada Materi Sistem Gerak Pada Tubuh Manusia" menyatakan bahwa hasil dari penelitian ini yaitu model pembelajaran Grup Investigation (GI) dipadukan dengan media WA Grup (kelas eksperimen) memberi pengaruh lebih baik pada saat digunakan untuk membahas materi Sistem Gerak Pada Manusia di kelas VIII SMP Negeri 19 Kota Tasikmalaya dengan skor rata-rata pretest 13,44 , skor rata-rata posttest 23,81 dan skor rata-rata $\mathrm{N}$-gain 0.55 . Sedangkan untuk kelas yang proses pembelajarannya hanya menggunakan model pembelajaran Group Investigation (GI) (kelas kontrol) rata-rata skor pretest 12,43 , skor rata-rata posttest 20,97 dan skor rata-rata $\mathrm{N}$-gain 0,45 .

Penelitian ini sama-sama meneliti mengenai pengaruh media sosial WhatsApp terhadap hasil belajar siswa, yang membedakan penelitian di atas dengan penelitian yang akan dilakukan 
oleh peneliti yaitu: penelitian di atas mencari pengaruh penggunaan media WhatsApp (WA) grup terhadap hasil belajar peserta didik pada materi sistem gerak pada manusia, metode penelitian di atas menggunakan metode penelitian True Eksperimental, sedangkan penelitian ini menggunakan pengaruh pemanfaatan media sosial WhatsApp terhadap hasil belajar Pendidikan Agama Hindu dan Budi Pekerti dengan menggunakan metode penelitian kuantitatif asosiatif dengan jenis korelasional. Dan tujuan dari penelitian ini adalah untuk mengetahui pengaruh pemanfaatan media sosial WhatsApp terhadap hasil belajar agama Hindu dan Budi Pekerti siswa kelas X di SMK Negeri 4 Mataram tahun pelajaran 2020/2021.

Menurut Susanti dalam Kamila (2019) Media sosial merupakan perkembangan dari teknologi-teknologi web berbasis internet, memudahkan semua orang untuk berkomunikasi dan berpartisipasi. Jumiatmoko (2016), mengatakan WhatsApp merupakan media berbasis internet yang memungkinkan setiap penggunanya dapat saling berbagi berbagai macam konten sesuai dengan fitur pendukungnya. WhatsApp dilengkapi dengan berbagai fitur dengan keunggulan yang dimiliki yang dapat digunakan untuk berkomunikasi dengan bantuan layanan internet. Adapun fungsi media WhatsApp yang dapat dimanfaatkan, diantaranya adalah bisa mengirim pesan, Chat Group, berbagi foto, video dan dokumen. Adapun manfaat grup WhatsApp dalam pembelajaran yaitu, 1) grup WhatsApp memberikan fasilitas pembelajaran secara kolaboratif antara guru dan siswa ataupun sesama siswa baik di rumah maupun di sekolah, 2) grup WhatsApp merupakan aplikasi gratis yang mudah digunakan, 3) grup WhatsApp dapat digunakan untuk berbagi komentar, tulisan, gambar, video, suara dan dokumen, 4) grup WhatsApp memberikan kemudahan untuk menyebarluaskan pengumuman, 5) informasi dan pengetahuan dapat dengan mudah dibuat dan disebarluaskan melalui berbagai fitur. Menurut Ricu Sidiq dalam Lestari (2021) media sosial WhatsApp mempunyai beberapa kelebihan. Adapun beberapa kelebihan dari media sosial WhatsApp yakni penggunaannya yang mudah, praktis, cepat, hemat data internet dan dapat diakses hanya dengan menggunakan handphone, memiliki berbagai fitur yang dapat digunakan untuk berkomunikasi seperti adanya New Group, WhatsApp Web, dan Setting dengan bantuan layanan internet.

Berdasarkan penjelasan di atas maka dapat disimpulkan bahwa WhatsApp merupakan media sosial berbasis internet yang digunakan untuk mempermudah penyebaran informasi dan semua orang bisa dengan mudah memanfaatkan fiturfitur yang disediakan, salah satunya penggunaan Group WhatsApp oleh guru dan siswa sebagai tempat berdiskusi serta berkomunikasi dalam proses pembelajaran.

Menurut Morgan dalam Thobroni (2015) belajar adalah setiap perubahan yang relatif menetap dalam tingkah laku yang terjadi sebagai suatu hasil dari latihan atau pengalaman. Hasil belajar menurut Gagne \& Briggs dalam Dahar (2011) adalah kemampuan-kemampuan yang dimiliki siswa sebagai akibat perbuatan belajar dan dapat diamati melalui penampilan siswa (learner's performance). Gagne mengemukakan lima macam hasil belajar, tiga diantaranya bersifat kognitif, afektif dan psikomotorik. Dalam kitab Manawadharmasastra, III.70 ditegaskan bahwa "Adhyapanam brahma yajnah, pity yajnastu tarpanam, homo daiwo balibhaurto, nryajno tithi pyujanam" yang artinya mengajar dan belajar adalah yadnya bagi brahmana, menghaturkan tarpana dan air suci adalah yadnya untuk leluhur, menghaturkan minyak dan susu adalah yadnya untuk para dewa, mempersembahkan bali adalah yadnya untuk bhuta, dan penerimaan tamu dengan ramah adalah yadnya untuk manusia (Girinata, 2016). Guru diibaratkan sebagai brahmana yang 
berkewajiban untuk memberikan ilmu pengetahuan dan juga menanamkan karakter yang baik bagi siswa agar dapat berguna bagi dirinya dan masyarakat. Pembelajaran agama Hindu sangat penting diberikan kepada siswa karena di dalam pembelajaran agama Hindu menekankan pada segi spiritual keagamaan dan merupakan suatu bimbingan kepada siswa agar memiliki budi pekerti yang luhur.

Berdasarkan beberapa uraian diatas, dapat disimpulkan bahwa hasil belajar adalah kemampuan yang dimiliki siswa setelah menerima pengalaman belajarnya yang dinilai dari aspek kognitif, afektif dan psikomotorik. Permasalahan inilah yang berupaya untuk peneliti pecahkan, yang mana akan berupaya diungkap pengaruh pemanfaatan media sosial WhatsApp terhadap hasil belajar Pendidikan Agama Hindu dan Budi Pekerti siswa kelas X SMK Negeri 4 Mataram.

\section{METODE}

Penelitian yang dilakukan di SMK Negeri 4 Mataram ini termasuk penelitian asosiatif dengan jenis korelasional karena penelitian ini mencari ada tidaknya hubungan antara dua variabel atau lebih. Jadi ada variabel independen (variabel yang mempengaruhi) yaitu media sosial WhatsApp, dan dependen (dipengaruhi) yaitu hasil belajar siswa. Pendekatan yang digunakan dalam penelitian ini adalah pendekatan kuantitatif karena dalam penelitian ini dituntut menggunakan angka, mulai dari pengumpulan data, analisis data maupun penyajian data. untuk dipelajari dan kemudian ditarik kesimpulannya (Sugiyono, 2018). Populasi dalam penelitian ini adalah seluruh siswa agama Hindu kelas $\mathrm{X}$ yang terdiri dari 5 jurusan yaitu: Jurusan Akomodasi Perhotelan, Tata Boga, Tata Busana, Tata Kecantikan dan Usaha Perjalanan Wisata yang berjumlah 83 siswa. Pengambilan sampel pada penelitian ini menggunakan teknik Probability Sampling, yaitu dengan Simple Random Sampling. Teknik ini dikatakan simple (sederhana) karena pengambilan anggota sampel dari populasi dilakukan secara acak tanpa memperhatikan strata yang ada dalam populasi itu. Rumus yang digunakan untuk menentukan sampel dalam penelitian ini yaitu menggunakan rumus Yamane. Berdasarkan perhitungan menggunakan rumus Yamane maka sampel dalam penelitian ini adalah berjumlah 69 siswa dengan taraf kesalahan 5\%. Uji instrumen dalam penelitian ini menggunakan uji validitas dengan menggunakan rumus korelasi Product Moment Pearson dan uji reliabilitas menggunakan rumus Alpha Crobach.

Teknik pengumpulan data dalam penelitian ini menggunakan kuesioner/angket dan dokumentasi. Penelitian ini merupakan penelitian asosiatif dengan jenis korelasional sehingga teknis analisis data dalam penelitian ini menggunakan analisis korelasi Product Moment Pearson yang akan dibantu dengan SPPS 17. Bentuk pengujian hipotesis yang akan diuji dalam penelitian ini dapat dirumuskan sebagai berikut, HA: ada pengaruh pemanfaatan media sosial WhatsApp terhadap hasil belajar agama Hindu dan budi pekerti siswa kelas X di SMK Negeri 4 Mataram tahun pelajaran 2020/2021, HO: tidak ada pengaruh pemanfaatan media sosial WhatsApp terhadap hasil belajar agama Hindu siswa kelas $\mathrm{X}$ di SMK Negeri 4 Mataram tahun pelajaran 2020/2021. Dengan kriteria jika $r_{\text {hitung }}>r_{\text {tabel }}$ maka HO ditolak dan HA diterima dan jika $r_{\text {hitung }}<$ $\mathrm{r}_{\text {tabel }}$ maka HO diterima dan HA ditolak dengan $\alpha=0,05$.

\section{HASIL DAN PEMBAHASAN \\ Hasil}

Media Sosial WhatsApp

Data variabel pemanfaatan media sosial WhatsApp diperoleh melalui pengisian angket yang terdiri dari 29 item dengan jumlah responden 69 siswa. Berdasarkan tabulasi angket yang telah diisi oleh siswa diperoleh skor tertinggi 
sebesar 145 dan skor terendah sebesar 104 dari 69 responden. Berdasarkan perhitungan SPSS 17 dari data kuesioner variabel media sosial WhatsApp diperoleh nilai Mean (M) sebesar 134,67, Median (Me) sebesar 137,00, Modus (Mo) sebesar 145,00 dan Standar Deviasi (SD) sebesar 8,978 .

\section{$\underline{\text { Hasil Belajar }}$}

Data hasil belajar siswa diperoleh dari hasil nilai rapor semester ganjil pada mata pelajaran Pendidikan Agama Hindu dan Budi Pekerti siswa kelas $\mathrm{X}$ dengan jumlah 69 siswa. Skor tertinggi yang diperoleh siswa kelas $X$ pada mata pelajaran Pendidikan Agama Hindu dan Budi Pekerti di SMK Negeri 4 Mataram yaitu 96 dan skor terendah 86. Berdasarkan perhitungan SPSS 17 hasil analisis diperoleh nilai Mean (M) sebesar 91,02, Median (Me) sebesar 91,00, Modus (Mo) sebesar 95,00 dan Standar Deviasi (SD) sebesar 3,11.

Berdasarkan hasil perhitungan dengan bantuan SPSS versi 17, maka ringkasan hasil Kolmogorov-Smirnov kedua variabel, yaitu media sosial WhatsApp sebesar 0,164 lebih besar dari nilai uji signifikan yaitu 0,05 dan hasil belajar sebesar 0,122 lebih besar dari nilai uji signifikan yaitu sebesar 0,05. Berdasarkan kriteria uji signifikan maka disimpulkan bahwa data kedua variabel yaitu variabel media sosial WhatsApp dan hasil belajar berdistribusi normal sehingga bisa dilanjutkan untuk analisis selanjutnya. Untuk mengetahui nilai signifikan $(\alpha)$ masing-masing variabel bisa dilihat pada tabel berikut.

Tabel 1 Hasil Uji Normalitas dengan Kolmogorov-Smirnov One-Sample KolmogorovSmirnov Test

\begin{tabular}{|ll|r|r|}
\hline & & $\begin{array}{c}\text { Media Sosial } \\
\text { WhatsApp }\end{array}$ & Hasil Belajar \\
\hline $\mathrm{N}$ & & 69 & 69 \\
Normal Parameters & $\mathrm{a}, \mathrm{b}$ & 134.6667 & 91.0290 \\
& Mean & 8.97655 & 3.11529 \\
Most Extreme & Std. Deviation & .135 & .142 \\
Differences & Absolute & .110 & .139 \\
& Positive & -.135 & -.142 \\
Kolmogorov-Smirnov Z & Negative & 1.118 & 1.182 \\
Asymp. Sig. (2-tailed) & & .164 & .122 \\
\hline
\end{tabular}

- Test distribution is Normal

Berdasarkan taraf signifikansi 0,05, $\mathrm{r}_{\text {tabel }}$ untuk sampel 69 siswa sebesar 0,235. Sehingga koefisien korelasi $r_{x y}=0,378>$ koefisien korelasi $r_{\text {tabel }}=0,235$. Ini berarti terdapat pengaruh pemanfaatan media sosial WhatsApp terhadap hasil belajar Pendidikan Agama Hindu dan Budi Pekerti siswa kelas X di SMK Negeri 4 Mataram, dengan kontribusi sebesar 14,28\%. Jadi, hipotesis nol (Ho) yang menyatakan bahwa tidak ada pengaruh antara pemanfaatan media sosial WhatsApp terhadap hasil belajar Pendidikan Agama Hindu dan Budi Pekerti siswa kelas X di SMK Negeri 4
Mataram ditolak. Sementara, hipotesis alternatif (Ha) yang menyatakan bahwa ada pengaruh pemanfaatan media sosial WhatsApp terhadap hasil belajar Pendidikan Agama Hindu dan Budi Pekerti siswa kelas X di SMK Negeri 4 Mataram diterima.

Hasil perhitungan pengaruh pemanfaatan media sosial WhatsApp terhadap hasil belajar Pendidikan Agama Hindu dan Budi Pekerti siswa kelas X di SMK Negeri 4 Mataram berdasarkan SPPS 17 dapat dilihat sebagai berikut: 
Tabel 2 Hasil SPSS antara Media Sosial WhatsApp dan Hasil Belajar.

Correlations

\begin{tabular}{|cc|c|c|}
\hline & & $\begin{array}{c}\text { Media Sosial } \\
\text { WhatsApp }\end{array}$ & Hasil Belajar \\
\hline Media Sosial & Pearson Correlation & 1 & $.378^{* *}$ \\
WhatsApp & Sig. (2-tailed) & & .001 \\
& $\mathrm{~N}$ & 69 & 69 \\
\hline Hasil Belajar & Pearson Correlation & $.378^{* *}$ & 1 \\
& Sig. (2-tailed) & .001 & \\
& $\mathrm{~N}$ & 69 & 69 \\
\hline
\end{tabular}

**. Correlation is significant at the 0.01 level (2-tailed).

\section{Pembahasan}

Pengaruh pemanfaatan media sosial WhatsApp terhadap hasil belajar Pendidikan Agama Hindu dan Budi Pekerti siswa kelas X di SMK Negeri 4 Mataram tahun pelajaran 2020/2021.

Berdasarkan hasil perhitungan statistik taraf signifikansi $0,05, \mathrm{r}_{\text {tabel }}$ untuk sampel 69 siswa sebesar 0,235 . Sehingga koefisien korelasi $r_{\mathrm{xy}}=0,378>$ koefisien korelasi $r_{\text {tabel }}=0,235$. Ini berarti terdapat pengaruh pemanfaatan media sosial WhatsApp terhadap hasil belajar Pendidikan Agama Hindu dan Budi Pekerti siswa kelas X di SMK Negeri 4 Mataram, namun interpretasi menunjukkan bahwa korelasi yang terjadi antara kedua variabel dalam penelitian ini memiliki tingkat hubungan yang rendah.

Jadi dapat disimpulkan bahwa hasil belajar tidak hanya dipengaruhi oleh media sosial WhatsApp, namun juga dipengaruhi oleh media pembelajaran lain yang dapat membantu dan mempermudah dalam menunjang pembelajaran siswa. Perkembangan teknologi di era modern sangat mudah diakses oleh siswa kapanpun dan di manapun. Hampir semua alat komunikasi seperti Smartphone menyediakan aplikasi yang memudahkan penggunanya untuk mengakses internet.

$$
\text { Menurut Tasker teori }
$$
konstruktivisme adalah peran aktif siswa dalam mengonstruksi pengetahuan secara bermakna dan mengaitkan antara gagasan dan informasi baru yang diterima
(Thobroni, 2015). Berdasarkan teori ini siswa harus inovatif dan aktif untuk belajar menemukan sendiri kompetensi, pengetahuan maupun teknologi yang diperlukan guna untuk mengembangkan dirinya. Hal ini sesuai dengan kondisi pembelajaran dimasa Covid-19 di mana siswa dituntut untuk terampil dalam menggunakan teknologi sebagai penunjang dalam proses pembelajaran.

Kontribusi pemanfaatan media sosial WhatsApp terhadap hasil belajar Pendidikan Agama Hindu dan Budi Pekerti siswa kelas X di SMK Negeri 4 Mataram tahun pelajaran 2020/2021.

Untuk menghitung besarnya kontribusi pemanfaatan media sosial WhatsApp terhadap hasil belajar Pendidikan Agama Hindu dan Budi Pekerti siswa kelas $\mathrm{X}$ di SMK Negeri 4 Mataram digunakan rumus $r^{2} x 100 \% . r_{x y}$ adalah nilai korelasi antara variabel media sosial WhatsApp terhadap hasil belajar. Berdasarkan perhitungan SPSS 17 nilai $\mathrm{r}_{\mathrm{xy}}$ $=0,378$. Jadi $r^{2}=0,378 \times 0,378 \times 100 \%=$ $14,28 \%$. Ini artinya ada faktor lain sebesar $85,72 \%$ yang berpengaruh terhadap hasil belajar Pendidikan Agama Hindu dan Budi Pekerti siswa kelas X di SMK Negeri 4 Mataram tahun pelajaran 2020/2021.

Hasil belajar tidak hanya ditentukan oleh sarana dan prasarana yang dimiliki oleh siswa seperti pemanfaatan media sosial WhatsApp tetapi juga dipengaruhi oleh faktor lain. Adapun 
faktor lain yang mempengaruhi hasil belajar seperti faktor lingkungan belajar, faktor keluarga, faktor kecerdasan siswa serta beberapa faktor lain baik dalam diri siswa maupun dari luar.

\section{PENUTUP}

\section{Simpulan}

Berdasarkan hasil perhitungan uji hipotesis, dapat disimpulkan pada penelitian ini adalah menerima alternaif hipotesis (Ha) dan menolak hipotesis nol (Ho). Ini berarti bahwa terdapat pengaruh pemanfaatan media sosial WhatsApp terhadap hasil belajar Pendidikan Agama Hindu dan Budi Pekerti di SMK Negeri 4 Mataram tahun pelajaran 2020/2021 dengan hasil perhitungan statistik taraf signifikansi $0,05, \mathrm{r}_{\text {tabel }}$ untuk sampel 69 siswa sebesar 0,235. Sehingga koefisien korelasi $\mathrm{r}_{\mathrm{xy}}=0,378>$ koefisien korelasi $r_{\text {tabel }}=0,235$.

Kontribusi pemanfaatan media sosial WhatsApp terhadap hasil belajar adalah $14,28 \%$. Ini berarti ada faktor lain sebesar $85,72 \%$ berkontribusi terhadap hasil belajar Pendidikan Agama Hindu dan Budi Pekerti siswa kelas X di SMK Negeri 4 Mataram tahun pelajaran 2020/2021, seperti faktor lingkungan belajar, faktor keluarga, faktor kecerdasan siswa serta beberapa faktor lain baik dalam diri siswa maupun dari luar.

\section{Saran}

Berdasarkan hasil pembahasan dan kesimpulan di atas, ada beberapa saran yang dapat direkomendasikan dalam penelitian ini:

\section{Guru}

Bagi guru agama Hindu agar dapat mengembangkan keahlian dalam penggunaan media sosial WhatsApp, sehingga fitur-fitur yang tersedia dalam WhatsApp dapat dimanfaatkan secara maksimal dan sebagai media penyampaian pesan mengenai pembelajaran maupun pengumuman secara virtual menjadi lebih menarik.
2. Sekolah

Bagi sekolah agar dapat meningkatkan sarana-prasarana yang lebih menunjang guna dapat menggunakan media internet (media sosial) dalam kegiatan belajar, seperti jaringan internet (wifi) gratis dengan kualitas terbaik sehingga dapat digunakan sesuai kebutuhan siswa.

3. Siswa

Bagi siswa diharapakan tidak menggunakan media sosial WhatsApp sebagai hiburan semata, namun harus bijak dalam menggunakan media sosial WhatsApp sehingga dapat dimanfaatkan untuk menunjang pembelajaran.

4. Peneliti selanjutnya

Bagi peneliti selanjutnya diharapkan untuk mencari faktor lain yang dapat mempengaruhi hasil belajar Pendidikan Agama Hindu dan Budi Pekerti selain media sosial WhatsApp.

\section{DAFTAR PUSTAKA}

Dahar, Ratna Wilis. (2006). Teori-teori Belajar \& Pembelajaran. Jakarta: Erlangga

Girinata, I Made. (2016). Acara Agama Hindu I. Denpasar: Institut Agama Hindu Dharma Negeri Denpasar Jumiatmoko. (2016). WhatsApp Messenger Dalam Tinjauan Manfaat Dan Adab. Jurnal Pendidikan Agama Islam. Sekolah Tinggi Ilmu Tarbiyah Madinah Sragen.

http://journal.walisongo.ac.id. (diakses pada tanggal 25/04/2021, pukul 14:30).

Kamila, Hilwa Putri. (2019). Pengaruh Pemanfaatan Media Sosial WhatsApp Terhadap Motivasi Belajar Bahasa Indonesia Di SMP Islam Al Wahab Jakarta Tahun Pelajaran 2018/2019. Skripsi. Universitas Islam Negeri Syarif 
Hidayattulah.

http://repository.uinjkt.ac.id.

(diakses pada tanggal 30/03/2021, pukul 12:26).

Lestari, Wiji. (2021). Pemanfaatan WhatsApp Sebagai Media Pembelajaran Dalam Jaringan Masa Pandemi Covid-19 di Kelas VI Sekolah Dasar. Skripsi. Universitas Jambi. https://repository.unja.ac.id. (diakses pada tanggal 4/04/2021, pukul 08:53).

Mustofa, K., P. dan Nuryadin, E. (2018). Pengaruh Penggunaan Media WhatsApp (WA) Group Terhadap Hasil Belajar Peserta Didik Pada Materi Sistem Gerak Pada Tubuh Manusia Kelas VIII SMP Negeri Kota Tasikmalaya. Jurnal Pendidikan Ekonomi. Universitas Siliwangi. https://journal.institutpendidikan.ac .id. (diakses pada tanggal 28/03/2021, pukul 10:15).

Sudrajat, A. (2010) Definisi Pendidikan Menurut UU No. 20 Tahun 2003, pada:

https://akhmadsudrajat.wordpress.c om/2010/12/04/definisi-

pendidikan-definisi-pendidikanmenurut-uu-no-20-tahun-2003tentang-sisdiknas.

Sugiyono. (2018). Metode Penelitian Kuantitaif. Bandung: Alfabeta.

Thobroni, M. (2015). Belajar \& Pembelajaran Teori \& Praktik. Yogjakarta: Ar-Ruzz Media.

Widarjono, A. (2010). Analisis Statistika Multivariat Terapan. Yoyakarta: Sekolah Tinggi Ilmu Manajemen YKPM. 